\title{
Evaluasi Pembiayaan Perumahan Akad Murabahah Versus Kredit Konvensional Berdasarkan Volatilitas Harga
}

Riwayat Artikel:Diterima 17 Sep 2015 Direvisi 20 Okt 2015 Disetujui 30 Nov 2015

\section{SAHLAN HASBI* \& KUNCORO HADI}

Program Studi Ekonomi dan Keuangan Syariah,Universitas Indonesia, Jl. Prof. Dr. Sumitro Djojohadikusumo UI Depok 16424, Tel. 021 - 727 2425, 727 2646, Indonesia.

*Corresponding Author, E_mail address: sahlan.hasbi@gmail.com

\begin{abstract}
The purpose of this study was to determine whether the pattern of housing financing murabaha or conventional mortgages can overcome the volatility of house prices after the maturity of the financing. The data used is the housing finance murabaha installment in Bank Syariah Mandiri and Bank BRISyariah and conventional housing loan installment consumer loan interest is based on the National Private Bank. The study says that housing finance murabaha at bank Syariah Mandiri, Bank BRISyariah and conventional mortgages experienced a capital loss caused due to the volatility of house prices where the market value of the home after the maturity of the financing is higher than the value of the house based on murabaha financing and conventional loans.

Keywords: Murabaha Contract; Mortgage Financing; Effectively the Floating Rate; Volatility of Prices; Capital Loss
\end{abstract}

\section{ABSTRAK}

Tujuan dari penelitian ini adalah untuk menentukan apakah pola murabahah pembiayaan perumahan atau KPR konvensional dapat mengatasi volatilitas harga rumah setelah jatuh tempo pembiayaan. Data yang digunakan adalah pembiayaan perumahan murabahah angsuran di Bank Syariah Mandiri dan Bank BRISyariah dan KPR bunga kredit angsuran konsumen konvensional didasarkan pada Bank Swasta Nasional. Studi ini mengatakan bahwa murabahah pembiayaan perumahan di bank Syariah Mandiri, Bank BRISyariah dan hipotik konvensional mengalami kerugian modal disebabkan karena volatilitas harga rumah di mana nilai pasar rumah setelah jatuh tempo pembiayaan yang lebih tinggi dari nilai rumah berdasarkan pembiayaan murabahah dan pinjaman konvensional.

Kata Kunci:Kontrak Murabahah; Pembiayaan KPR; Suku Bunga Efektif; Volatilitas Harga; Kerugian Modal

\section{PENDAHULUAN}

Selama periode tahun 2013, pelayanan kebutuhan masyarakat akan perbankan syariah semakin meluas. Hal itu tercermin dari bertambahnya kantor cabang perbankan syariah dari sebanyak 386 menjadi 407 kantor. Sementara Kantor Cabang Pembantu (KCP) dan Kantor Kas (KK) telah bertambah sebanyak 232 kantor pada periode yang sama. Secara keseluruhan jumlah kantor perbankan syariah yang beroperasi sampai dengan bulan Desember 2013 dibandingkan tahun sebe-lumnya meningkat dari 1.745 kantor menjadi 1.998 kantor (www.bi.go.id).
Bank Syariah, sebagaimana bank konvensional, juga berfungsi sebagai suatu lembaga intermediasi (intermediary institution), yaitu mengerahkan dana dari masyarakat dan menyalurkan kembali dana tersebut kepada masyarakat yang membutuhkannya dalam bentuk fasilitas pembiayaan. Pembiayaan merupakan salah satu kegiatan utama dan menjadi sumber utama pendapatan bagi bank syariah. Bentuk pembiayaan perbankan berdasarkan prinsip syariah yaitu: berdasarkan prinsip jual beli barang pada harga asal dengan tambahan keuntungan yang disepakati (mura-bahah), pembelian barang yang 
TABEL I. POSISI PRODUK PIUTANG MURABAHAH PERBANKAN SYARIAH

\begin{tabular}{lllllllll}
\hline Tahun & 2006 & 2007 & 2008 & 2009 & 2010 & 2011 & 2012 & 2013 \\
\hline $\begin{array}{l}\text { Outstanding Piutang Murabahah } \\
\text { Porsi Piutang Murabahah Terhadap Total }\end{array}$ & 12.624 & 16.553 & 22.486 & 25.046 & 37.508 & 56.365 & 88.004 & 110.565 \\
$\begin{array}{l}\text { Pembiayaan } \\
\text { Sumber : Statistik Perbankan Syariah Bank Indonesia (2004-2011) (www.bi.go.id). }\end{array}$ & $59.2 \%$ & $58.9 \%$ & $56.3 \%$ & $55.0 \%$ & $54.9 \%$ & $59.7 \%$ & $60.0 \%$ \\
\hline
\end{tabular}

diserahkan di kemudian hari sementara

pembayarannya dilakukan di muka (salam), pembelian barang yang dilakukan dengan kontrak penjualan yang disepakati (istishna'), pemindahan hak guna atas barang dan jasa tanpa diikuti dengan pemindahan kepemilikan (ijarah), kerjasama usaha antara dua pihak dimana pihak pertama menyediakan modal 100\% sedangkan pihak lain menjadi pengelola (mudharabah), pembiayaan berdasarkan prinsip penyertaan modal (musharakah), jaminan yang diberikan oleh bank kepada pihak ketiga untuk memenuhi kewajiban pihak kedua (kafalah), pengalihan hutang (hawalah), dan pemberian harta kepada orang lain yang dapat ditagih dan diminta kembali (qardh) (Antonio, 2009).

Berdasarkan data Statistik Perbankan Syariah tahun 2013 yang dikeluarkan oleh Bank Indonesia (www.bi.go.id), perbankan syariah mampu tumbuh sekitar 24\% dengan total aset Rp 242,276 triliun. Pembiayaan telah mencapai Rp 184,12 triliun dan penghimpunan dana telah mencapai angka Rp183,53 triliun. Penghimpunan dana masyarakat terbesar diperoleh dalam bentuk Deposito yaitu Rp 107,81 triliun $(58,74 \%$ dari total penghim-punan dana) diikuti oleh Tabungan sebesar Rp 57,20 triliun (31,17\%) dan Giro sebesar Rp 18,52 triliun (10,09\%). Penyaluran dana masih didominasi piutang murabahah sebesar Rp 110,56 triliun atau $60,05 \%$ dari total penyaluran dana, diikuti pembiayaan Musyarakah sebesar Rp 39,87 triliun (21,71\%) dan pembiayaan Mudharabah sebesar Rp
13,62 triliun (7,40\%), serta pembiayaan Ijarah sebesar Rp 10,48 triliun (5,69\%).

Dominannya pembiayaan murabahah yang disalurkan kepada masyarakat bisa dimaklumi karena rasionalisasi yang dijadikan alasan oleh bank antara lain karena bank syariah cenderung ingin memperoleh pendapatan yang tetap (fixed income) dari tingkat margin murabahah yang telah ditentukan di depan tersebut, sehingga bank syariah sebagai mudharib dapat memberikan nisbah bagi hasil yang cukup menarik bagi para shahibul mal (deposan dan penabung mudharabah). Semakin tinggi margin yang diminta bank kepada nasabah pembeli (murabahah) maka semakin besar pula pendapatan bank syariah yang dibagikan kepada shahib mal-nya. Pada gilirannya sumber dana mudharabah yang dihimpun dapat dipertahankan jumlahnya bahkan diharapkan semakin meningkat.

Perkembangan pembiayaan muraba-hah dari tahun 2006 sampai dengan 2013 dapat disimak pada Tabel 1. Jumlah outstanding piutang murabahah di perbankan syariah setiap tahun semakin meningkat dari Rp 12.626 milyar pada 2006 hingga Rp 110.565 milyar pada 2013. Sedangkan porsi piutang murabahah terhadap total pembiayaan secara prosentase memang sedikit mengalami penurunan dari $61.8 \%$ di tahun 2006 menjadi $60.0 \%$ di tahun 2013. Akan tetapi penurunan prosentase ini berbanding terbalik dengan tingkat outstanding piutang murabahah yang justru semakin meningkat. Itu artinya, dari aspek pembiayaan yang lain di perbankan syariah juga mengalami 
peningkatan, sehingga pembiayaan murabahah menjadi menurun dari segi prosentase. Dan secara tidak langsung hal itu menggambarkan prospek perbankan syariah yang setiap tahun semakin dinamis.

Dalam perspektif fiqih, murabahah sendiri merupakan transformasi dari bentuk peminjaman tradisional ke dalam bentuk perjanjian jual beli, dimana kedua belah pihak harus menyepakati harga jual dan jangka waktu pembayaran. Dalam hukum Islam, jual beli hukumnya jaiz (boleh).

Dalam murabahah, ketika harga jual dicantumkan dalam akad jual beli dan jika telah disepakati maka harga tersebut tidak dapat berubah selama berlakunya akad. Apabila terjadi perubahah maka akad tersebut menjadi batal. Cara pembayaran dan jangka waktu murabahah disepakati bersama oleh para pelaku akad, boleh secara lumpsum ataupun secara angsuran. Begitu juga dengan pembiayaan murabahah untuk kepemilikan rumah (KPR) di bank syariah, yang mana tingkat keuntungan bank ditentukan di depan dan menjadi bagian harga atas rumah yang dijual. Harga dan keuntungan harus disebutkan, begitu pula sistem pembayarannya, semuanya ditetapkan di depan sebelum akad resmi (ijab qabul) dinyatakan secara tertulis.

Berbeda dengan pembiayaan perumahan di bank konvensional yang menggunakan suku bunga sebagai dasar untuk menetapkan besarnya angsuran. Bunga yang diberlakukan pada pembiayaan perumahan konvensional adalah bunga efektif dengan sistem floating (mengambang) sehingga besarnya angsuran setiap bulan akan berbeda. Hal ini disebabkan karena adanya perhitungan faktor bunga yang mempengaruhi besarnya cicilan setiap bulan. Kondisi ini menjadikan nasabah harus membayar angsuran mereka dalam jumlah yang berbeda untuk setiap bulan tergantung pada suku bunga pada bulan saat pembayaran dilakukan (Rama, 2011).

Berdasarkan teori ekonomi konvensional, yakni teori time value of money (Hanley dan Spash, 1993), bahwasanya apresiasi seseorang akan lebih tinggi terhadap nilai uang hari ini dibandingkan nilai mata uang yang akan datang karena terdapat positive time preference. Hal ini menyebabkan pula adanya kesenjangan harga suatu barang pada saat ini dan yang akan datang. Harga suatu barang tidak akan sama nilainya pada waktu yang berbeda dan akan cenderung naik seiring dengan perputaran waktu tidak terkecuali harga rumah. Kondisi Ini disebabkan oleh adanya inflasi pada suatu kegiatan ekonomi. Tingkat inflasi yang tinggi ikut memicu naiknya harga bahan bangunan dan tanah, yang berdampak pada melambungnya harga rumah.

Walcott (1987) mengemukakan empat faktor yang dapat mempengaruhi nilai harga rumah (tanah dan bangunan) antara lain pertama, faktor ekonomi yang ditunjukkan dengan hubungan permintaan dan penawaran yang disebabkan oleh kemampuan ekonomi suatu masyarakat untuk memenuhi kebutuhan dan keinginannya. Kedua, faktor sosial ditunjukkan dengan karakteristik penduduk, tingkat pendidikan dan lain lain yang membentuk pola penggunaan tanah pada suatu wilayah. Ketiga, faktor pemerintah, yakni kebijakan pemerintah dalam hal bidang pengembangan atau penggunaan tanah (zoning). Keempat, faktor fisik, antara lain tata letak atau lokasi dan ketersediaan fasilitas sosial. Interaksi faktor-faktor tersebut di atas menciptakan nilai yang tercermin dalam prinsip ekonomi permintaan dan penawaran yang dapat kita lihat sebagaimana hasil riset Indonesian Property Watch (IPW) yang dikutip dari Detik Finance yang mencatat kenaikan harga tanah (rumah) di kawasan Depok 15\%-24\% (lihat juga: Adrian Sutawijaya, 2004).

Kenaikan harga rumah ini sejalan dengan permintaan akan rumah di kota Depok yang 
GAMBAR 1. PERKEMBANGAN JENIS PROPERTI YANG TERSEDIA DI KOTA DEPOK

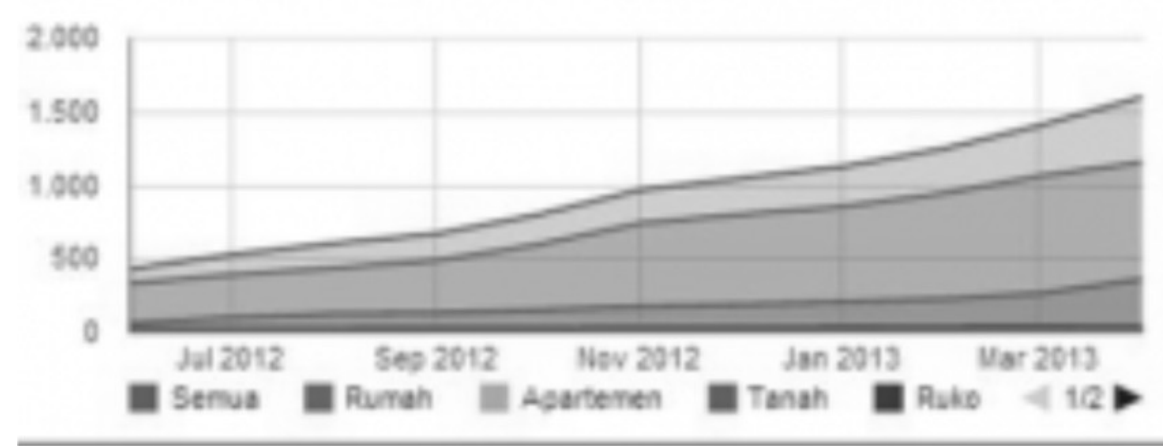

Sumber: http://masnov.com/trend-properti-di-kota-depok-2014

GAMBAR 2. PERKEMBANGAN HARGA RUMAH DI PERUMAHAN GRAND DEPOK CITY (GDC) DAN NILAI INFLASI DI INDONESIA

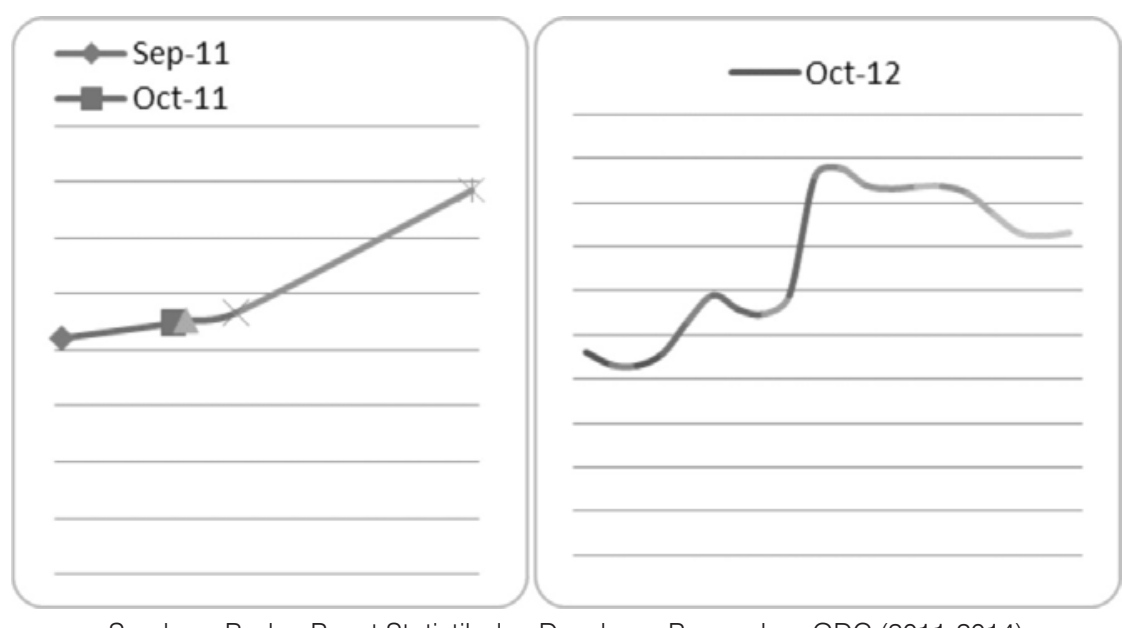

Sumber : Badan Pusat Statistik dan Developer Perumahan GDC (2011-2014)

semakin meningkat setiap tahunnya. Sebagaimana hasil perhitungan Area Analytics berdasarkan data dari UrbanIndo (2014), sejak bulan Juli 2012 hingga April 2013 pemasaran properti untuk daerah Depok setiap bulan selalu meningkat, di akhir bulan April 2013 total properti yang dipasarkan mencapai 1.602 properti. Total tersebut meliputi rumah sebanyak 1.157 buah, tanah 361 unit, sisanya ruko dan ruang usaha/properti komersial.

Secara spesifik, trend kenaikan harga rumah di Kota Depok dapat dilihat pada pola kenaikan rumah yang terjadi di perumahan Grand Depok City tipe Alamanda dengan Luas Bangunan $36 \mathrm{~m}^{2}$ dan Luas Tanah $90 \mathrm{~m}^{2}$ pada Juni tahun 2012 dengan harga Rp. 448 juta dan pada Juni 2014 sudah mencapai harga Rp. 685 juta atau naik sebesar $34.60 \%$ selama kurun waktu dua tahun. Kenaikan harga rumah ini sejalan dengan nilai inflasi yang selalu meningkat sebagaimana yang terlihat pada Gambar 2.

Kenaikan harga tanah dan bangunan di Kota Depok yang dinilai overvalue disebabkan oleh beberapa hal, yakni pembangunan infrastruktur berupa rencana pembangunan ruas tol DepokAntasari dan Cinere-Bogor-Jagorawi masing-masing sepanjang 18,2 kilometer dan 14 kilometer, munculnya fasilitas-fasilitas komersial baru diantaranya adalah Depok Town Square (Lippo), ITC Depok (Duta Pertiwi) dan Margo City Square (Djarum), Depok Town Center (Gapura Prima Grup) serta adanya rencana pembangunan Rumah 
Sakit Internasional di Universitas Indonesia sebagai rumah sakit pendidikan yang ikut memicu kenaikan harga tanah yang cukup signifikan (www.masnov.com).

Harga jual rumah dalam akad murabahah pada pembiayaan perumahan yang yang sudah ditentukan besarannya sejak awal akad dan bersifat tetap berpotensi terjadi kesenjangan jika dibandingkan dengan harga rumah yang cenderung selalu meningkat. Kondisi ini berpotensi menimbulkan risiko harga, yang merupakan volatilitas komoditas harga rumah sepanjang periode pembiayaan. Nasabah berpotensi mendapatkan manfaat moneter ketika harga barang yang dibiayai melalui akad murabahah akan naik melebihi harga awal ketika kontrak murabahah ditandatangani.

Jika kenaikan harga rumah melebihi tingkat margin pada murabahah yang sudah ditentukan di awal akad, maka bank berpotensi mengalami capital loss dan opportunity loss, karena akumulasi angsuran yang diperoleh tidak bisa lagi dipergunakan untuk berinvestasi pada obyek yang sama. Namun jika tingkat margin yang sudah ditentukan di awal akad bisa mengakomodasi kenaikan harga di masa yang akan datang, maka bank akan memperoleh keuntungan.

Berdasarkan paparan argumentasi di atas, maka penting untuk dilakukan kajian studi kasus apakah pembiayaan murabahah yang dilakukan oleh bank syariah memiliki risiko atas margin yang lebih kecil dari potensi kenaikan harga asset yang dimurabahah-kan. Oleh karena itu, fokus penelitian ini adalah untuk mengevaluasi model pembiayaan perumahan Syariah berbasis murabahah. Hasil penelitian ini diharapkan dapat memberikan gambaran informasi khususnya terkait manajemen risiko bank syriah dalam menetapkan nilai akad murabahah terkait kepemilikan rumah. Manajemen risiko penting menjadi pusat perhatian karena hal tersebut akan berkaitaa pada keberlanjutan usaha dan keberlanjutan profitabilitas suatu entitas, dalam hal ini adalah perbankan syariah.

\section{TINJAUAN LITERATUR DAN FOKUS PENELITIAN PEMBIAYAAN MURABAHAH}

Murabahah diambil dari kata "ribh" yang berarti keuntungan, keuntungan atau penambahan. Dalam Murabahah, penjual harus mengungkapkan biaya dan kontrak terjadi pada margin yang disepakati keuntungan. Kontrak ini dipraktekkan di zaman pra-Islam. Al-Marghinani (1957) telah mendefinisikan Murabahah sebagai penjualan berbagai macam barang dengan besaran harga yang sudah ditentukan oleh penjual dengan adanya penambahan keuntungan dalam jumlah yang tetap. Dengan demikian, penjual harus mengungkapkan kepada pembeli besaran modal yang dibutuhkan untuk usahanya atau memberitahu seberapa besar biaya yang sudah dikeluarkan. Menurut Imam Malik, Muraba-hah dilakukan dan diselesaikan dengan pertu-karan barang dimana harga yang dibebankan sudah termasuk margin keuntungan yang disepakati bersama. Berdasarkan definisi tersebut, dasar untuk Murabahah dinyatakan valid jika pembeli mengetahui harga dasar, biaya tambahan jika ada dan jumlah keuntungan (Zandi et al., 2012).

Dalam konteks pembiayaan murabahah dapat didefinisikan sebagai pembiayaan dengan harga pokok dan margin yang besarannya sudah ditentukan di depan dengan jangka waktu pembiayaan yang sudah pasti pula. Pembiayaan Murabahah menjadi skema pembiayaan favorit di banyak bank syariah di dunia. Hal ini disebakan oleh (a) tingkat pengembalian dari Murabahah yang telah ditentukan, tetap dan berkesinambungan (b) Pembiayaan untuk perdagangan tidak memerlukan 
banyak upaya untuk memantau, bekerja sama atau mengevaluasi seperti pembiayaan berbasis investasi dan (c) Risiko gagal bayar relatif rendah. Sementara bagi pengusaha, Murabahah memiliki kelelebihan karena (i) marjin tetap sepanjang periode pengembalian pembayaran (ii) Tidak ada biaya untuk keterlambatan pembayaran / default (iii) Menggunakan aset yang dibeli sebagai jaminan, dan lain lain (Ismal, 2009).

\section{PEMBIAYAAN PERUMAHAN DI PERBANKAN SYARIAH DAN PERBANKAN KONVENSIONAL}

Pembiayaan perumahan dalam istilah bank konvensional Kredit Pemilikan Rumah merupakan salah satu jenis pelayanan kredit yang diberikan oleh bank kepada para nasabah yang menginginkan pinjaman khusus untuk memenuhi kebutuhan dalam pembangunan rumah atau renovasi rumah. Pembiayaan perumahan sendiri muncul karena adanya kebutuhan memiliki rumah yang semakin lama semakin tinggi tanpa diimbangi daya beli yang memadai oleh masyarakat (Hardjono, 2008).

Skema kredit perumahan bank konvensional menjadikan suku bunga sebagai dasar keuntungan bank. Bunga atas pinjaman yang harus dibayarkan akan semakin besar dengan semakin panjangnya jangka waktu yang disepakati. Kondisi ini pada akhirnya juga berpengaruh terhadap besaran angsuran yang harus disetorkan nasabah karena adanya fluktuasi bunga yang dibebankan bank kepada nasabah. Teknik perhitungan bunga kredit perumahan konvensional pada umumnya terdiri dari (Rivai, 2006):

\section{ADD ON BASIS}

Pembebanan bunga setiap bulan tetap dari jumlah pinjamannya, demikian pula pokok pinjaman setiap bulannya juga dibayar sama sehingga cicilan setiap bulan sama sampai kredit lunas.

$$
\text { Rumusnya: } A \quad=\underline{M+i(M \times n)}
$$

$\mathrm{n}$

Dimana:

$$
\begin{array}{ll}
\mathrm{A} & =\text { Angsuran } \\
\mathrm{i} & =\text { Tingkat Suku Bunga } \\
\mathrm{M} & =\text { Pokok Pinjaman } \\
\mathrm{N} & =\text { Tenor }
\end{array}
$$

\section{EFFECTIVE INTEREST RATE/ ANNUITAS}

Pada Sistem ini, digunakan bunga (tahunan atau bulanan) yang dikenakan pada sisa pokok utang (saldo efektif). Besarnya cicilan bulanan adalah tetap dan terdiri dari cicilan pokok utang (principal repayment) dan cicilan bunga. Rumusnya adalah:

$\begin{array}{ll}\text { Angsuran } & =\frac{\mathrm{i} \times \mathrm{M}}{\frac{(1+\mathrm{i})^{\mathrm{n}}}{(1+\mathrm{i})^{\mathrm{n}}-1}} \\ \text { Di mana: } & =\text { Pokok Pinjaman } \\ \mathrm{M} & =\text { Tingkat Suku Bunga } \\ \mathrm{i} & =\text { Tenor Pinjaman }\end{array}$

Dalam prakteknya, metode pembebanan bunga pada kredit perumahan menggunakan suku bunga tetap (flat rate) dan suku bunga mengambang (floating rate). Dan yang paling sering digunakan bank konvensional adalah perhitungan angsuran dengan sistem bunga efektif dengan metode pembebanan bunga floating (mengambang). Bunga floating membebankan bunga dikaitkan dengan bunga yang ada di pasar uang sehingga bunga yang dibayar setiap bulan sangat tergantung dari bunga pasar uang pada bulan tersebut. Jumlah bunga yang dibayarkan dapat lebih tinggi atau lebih rendah dari bulan yang bersangkutan. Pada akhirnya hal ini juga berpengaruh terhadap cicilannya asetiap bulan (Kasmir, 2013). Kondisi ini secara akumulatif menjadikan jumlah keuntungan yang diterima bank konvensional akan berbeda-beda untuk tiap tahunnya.

Pembiayaan perumahan murabahah adalah 
pembiayaan rumah berbasis syariah, di mana unsurunsur suku bunga dan ketidakpastian yang dilarang. Tidak seperti Pembiayaan perumahan konvensional, pembiayaan perumahan syariah memiliki peneka-nan pada tingkat perolehan keuntungan (margin) yang telah disepakati sebelumnya antar penjual dan pembeli bukan dari suku bunga sehingga besarnya angka angsuran tidak akan berfluktuasi, bahkan jika terjadi kenaikan harga rumah.

Dalam pembiayaan rumah syariah, nasabah menentukan rumah yang diinginkan untuk dibeli dan bank membeli rumah dari pengembang/ pemilik dengan harga normal secara tunai, dan menjualnya kembali kepada nasabah dengan harga yang lebih tinggi, karena harga tersebut sudah termasuk mark up (margin keuntungan). Nasabah kemudian membayar kembali kepada bank secara cicilan (Maali et al., 2006). Selisih antara harga pasar (harga pokok) dan mark up harga (harga jual) adalah keuntungan bagi bank, yang dapat diterima dalam konteks pembiayaan perumahan syariah (Hamid et al., 2011).

Beberapa perbedaan antara kredit perumahan konvensional dan pembiayaan perumahan syariah, Pertama, di bawah sistem keuangan konvensional besarnya bunga yang dibebankan ditentukan atas dasar permintaan dan penawaran modal sementara berdasarkan perumahan syariah pembebanan sistem sewa terhadap properti ditentukan melalui permintaan dan penawaran aset nyata. Oleh karena itu pada kredit perumahan konven-sional tidak terkait dengan penciptaan utilitas sementara dalam pembiayaan perumahan syariah, sektor keuangan terkait erat dengan sektor riil. Tanpa memiliki keterkaitan antara keuangan dan sektor nyata, itu bagaikan pembiayaan semu yang tidak menambah nilai apapun kepada masyarakat secara keseluruhan.

Kedua, bank konvensional tidak memiliki underly- ing asset, maka berbagi risiko dan keuntungan dari properti tidak diperlukan sementara dalam pembiayaan syariah kepemilikan properti dan berbagi risiko serta manfaat melekat dengan kepemilikan. Setiap kerusakan atau kerugian yang terjadi pada properti bukan disebabkan oleh kelalaian nasabah akan dibagi oleh bank syariah dengan nasabah sesuai dengan porsi kepemilikan yang mereka punya dan kondisi ini tidak terjadi pada pembiayaan perumahan konvensional.

Ketiga, return untuk bank konvensional dimulai sejak tanggal fasilitas pemberian kredit dilakukan sementara kondisi ini tidak terjadi pada pembiayaan perumahan Syariah. Keempat, bank konvensional akan terus menerima angsuran (mengandung bunga dan pokok) bahkan jika properti tidak bisa digunakan dan membutuhkan beberapa perbaikan. Selama periode perbaikan bank syariah tidak menerima sewa. Akhirnya return bank konvensional ditetapkan berdasarkan bunga sementara pembiayaan perumahan syariah akan menerima sewa sebagai bagian dari segala apresiasi (depresiasi) (Hanif, 2010). Berikut adalah skema pembiayaan KPR Syari'ah dengan skim murabahah:

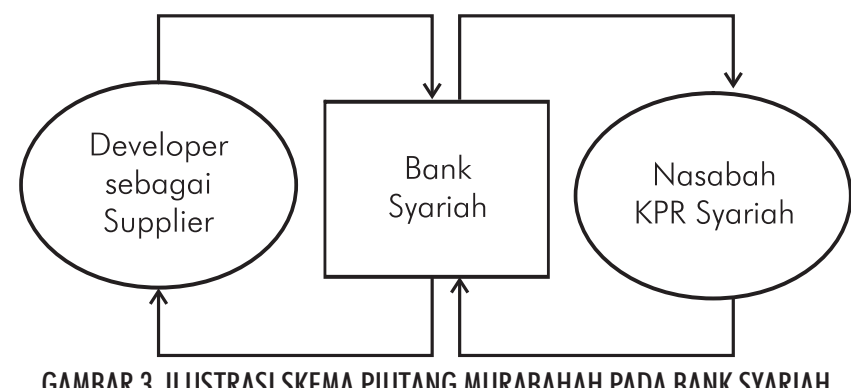

GAMBAR 3. ILUSTRASI SKEMA PIUTANG MURABAHAH PADA BANK SYARIAH Sumber: Karim (2010) dengan sedikit modifikasi

Keterangan:

1a: Developer perumahan menjual rumah kepada pihak bank syari'ah secara tunai.

1b: $\quad$ Bank syari'ah membeli kepada developer selaku supplier secara tunai.

2a: Bank syari'ah menjual rumah sebesar harga pokok/ asal ditambah keuntungan yang disepakati bersama, kepada nasabah pembiayaan perumahan syari'ah secara tangguh/ angsuran. 
2b: Nasabah membeli kepada bank syariah secara angsuran.

\section{VOLATILITAS HARGA RUMAH}

Volatilitas adalah pengukuran statistik untuk fluktuasi harga selama periode tertentu (Firmansyah, 2006). Volatilitas harga rumah menunjukkan penurunan dan peningkatan harga rumah dalam periode tertentu. Volatilitas harga pasar terjadi akibat masuknya informasi baru ke dalam pasar. Akibatnya para pelaku pasar melakukan penilaian kembali terhadap asset yang mereka perdagangkan. Pada pasar yang efisien, tingkat harga akan melakukan penyesuaian dengan cepat sehingga harga yang terbentuk mencerminkan informasi baru tersebut (Anton, 2006).

Nilai rumah (tanah dan bangunan) dalam konteks pasar properti adalah nilai pasar wajar yaitu nilai yang ditentukan atau ditetapkan oleh pembeli yang ingin membeli sesuatu dan penjual ingin menjual sesuatu berdasarkan persetujuan atau kesepakatan kedua belah pihak dalam kondisi wajar tanpa ada tekanan dari pihak luar pada proses transaksi jual beli sehingga terjadi kemufakatan. Pembeli dan penjual mempunyai tenggang waktu yang cukup atas properti yang diperjualbelikan dan bertindak untuk kepentingan sendiri.

Penentuan nilai suatu properti menurut American Institute of Real Estate Appraiser (Wolcott, 1987) dapat dilakukan melalui tiga pendekatan, yaitu pendekatan perbandingan data pasar (market data com-parison approach), pendekatan biaya (cost approach) dan pendekatan pendapatan (income approach).

Tanah mempunyai kekuatan ekonomis di mana nilai atau harga tanah sangat tergantung pada penawaran dan permintaan. Dalam jangka pendek penawaran sangat inelastis, ini berarti harga tanah pada wilayah tertentu akan tergantung pada faktor permintaan, seperti kepadatan penduduk dan tingkat pertumbu-hannya, tingkat kesempatan kerja dan tingkat pendapatan masyarakat serta kapasitas sistem transportasi dan tingkat suku bunga (Eckert, 1990).

Hasil penelitian Fahirah (2012), mengemukakan faktor-faktor yang dapat mempengaruhi nilai harga tanah dan bangunan antara lain:

1. Faktor ekonomi, ditunjukkan dengan hubungan permintaan dan penawaran dengan kemampuan ekonomi suatu masyarakat untuk memenuhi kebutuhan dan keinginannya. Variabel permintaan meliputi jumlah tenaga kerja, tingkat upah,daya beli masyarakat, tingkat pendapatan masyarakat dan tingkat suku bunga. Variabel penawaran meliputi jumlah tanah yang tersedia, biaya perijinan, pajak dan biaya overhead lainnya.

2. Faktor sosial, ditunjukkan dengan karakteristik penduduk yang meliputi jumlah penduduk, kepadatan penduduk, tingkat pendidikan, tingkat kejahatan, pola hidup masyarakat dan lain-lain. Setiap kawasan mempunyai ciri dan karakteristik tersendiri begitupun halnya dengan lingkungan perumahan. Untuk menciptakan lingkungan yang nyaman dan aman sebagai tempat tinggal tentunya ada beberapa hal penting yang menjadi aturan dan telah disepakati bersama. Hal ini biasanya menjadi pertimbangan dalam memilih tempat tinggal.

3. Faktor pemerintah (regulasi), seperti halnya berkaitan dengan ketentuan perundangundangan dan kebijakan pemerintah bidang pengembangan atau penggunaan tanah (zoning). Penyediaan fasilitas dan pelayanan oleh pemerintah mempengaruhi pola penggunaan tanah, misalnya fasilitas keamanan, kesehatan, pendidikan dan lain-lain.

4. Faktor fisik, antara lain kondisi lingkungan yang meliputi struktur/jenis tanah, kontur, bebas banjir, tata letak atau lokasi dan ketersediaan 
fasilitas sosial.

5. Aksesibilitas, yang meliputi ketersediaan transportasi (angkutan umum), kondisi jalan (aspal/belum), lebar jalan, jarak ke pusat kota, jarak ke tempat kerja, jarak ke sarana pendidikan.

6. Ketersediaan fasilitas. Ketersediaan fasilitas sangat mempengaruhi nilai tanah dan bangunan antara lain jaringan air bersih, jaringan listrik, pusat perbelanjaan, dan lain-lain.

\section{PENELITIAN TERDAHULU}

Beberapa penelitian terdahulu yang relevan dengan penelitian ini antara lain: Sudarso Kaderi Wiryono et al. (2011) menemukan, pertama, hanya Bukopin Syariah yang mengikuti kepatuhan Murabahah dengan kurva imbal hasil yang datar dan yang lain tidak. Kedua, rata-rata yield curve Bukopin Syariah sejak awal sampai akhir perjanjian pembiayaan perumahan Murabahah meng-ekspos hasil yang sangat tinggi untuk mengatasi secara signifikan atas dua risiko utama, yaitu risiko jatuh tempo dan risiko inflasi. Dan bank syariah lain mengadopsi kurva imbal hasil positif yaitu BNI Syariah, Mandiri Syariah, BRI Syariah, dan BTN Syariah dengan menerapkan tarif yang lebih rendah pada awal pembiayaan perumahan dan meningkat secara perlahan hingga jatuh tempo pembiayaan untuk mengatasi perbedaan rate deposito dan risiko yang muncul (risiko jatuh tempo dan risiko inflasi.

Penelitian lain dari Al-Mutairi (2010) menemukan pembiayaan rumah Islami tidak lebih mahal daripada pembiayaan rumah konvensional. 93\% dari responden memilih bank syariah karena kepatuhan prinsip syariah. Pada saat yang sama 70\% dari nasabah bank konvensional ingin beralih ke perbankan syariah. Mayoritas responden tidak tahu tentang perbedaan formal mengenai perbankan konvensional dan perbankan syariah.
Jadi kita bisa menganggap bahwa pelanggan sebelum memilih bank mereka untuk KPR yang tidak membuat analisis komparatif dari kedua sistem perbankan.

Selain itu, Habibullah (2005) menemukan pembiayaan murabahah yang memiliki return yang lebih baik adalah pembiayaan murabahah konsumsi dan pembiayaan murabahah yang memiliki risiko lebih kecil adalah pembiayaan murabahah modal kerja. Hasil uji $t$ mengha-silkan bahwa return semua pembiayaan tidak berbeda secara signifikan. Sedangkan Nugroho (2006) menemukan Bank Muamalat Indonesia periode Januari 2001 sampai dengan Desember 2004, diperoleh kesimpulan bahwa faktor biaya overhead, dan bagi hasil Dana Pihak Ketiga (DPK) secara signifikan mempengaruhi margin murabahah, sedangkan volume pembi-ayaan murabahah dan profit target tidak berpengaruh terhadap margin pembiayaan murabahah walaupun terdapat korelasi.

Dari penelitian-penelitian yang telah ada sebelumnya tersebut, penelitian ini memiliki persamaan, yakni membahas tentang pembi-ayaan murabahah dan pembiayaan perumahan serta halhal yang terkait dengan margin pembiayaan beserta risikonya. Dari sisi jenis obyek penelitian, penelitian Sudarso Kaderi Wiryono et al. (2011) merupakan penelitian yang memiliki kesamaan terdekat dengan penelitian ini, di mana sama-sama meneliti pada pembiayaan perumahan murabahah pada bank syariah di Indonesia, meskipun metode penelitiannya berbeda.

Adapun perbedaan penelitian ini dengan penelitian-penelitian tersebut ialah: (1) penelitian ini fokus pada isu keuntungan yang akan diperoleh bank syariah pada pembiayaan perumahan berakad murabahah (piutang murabahah) yang menggunakan fixed margin, dan jika dihitung berdasarkan bunga floating yang berlaku di bank konvensional; (2) penelitian ini dilakukan dengan studi kasus pada 
bank syariah Mandiri dan Bank BRI Syariah dengan kondisi yang terkini (update) karena menggunakan data kurun 9 tahun terakhir sebelum tahun pembuatan penelitian ini; dan (3) jenis penelitian adalah Causal Comparative dengan pengujian hipotesis menggunakan statistik analitik, yaitu dengan menggunakan uji-t sampel berpasangan (paired sample t-test).

\section{METODE PENELITIAN} JENIS PENELITIAN

Penelitian ini merupakan studi kasus, dari sudut pandang causal comparative atau dikenal juga dengan istilah ex post facto (setelah fakta), yakni penelitian yang mencoba menentukan suatu sebab dari sesuatu yang sudah terjadi. Variabel perlakuan pada desain penelitian ini merupakan kejadian yang sudah terjadi, maka tidak ada perlakuan (treatment) yang dilakukan oleh peneliti.

\section{DATA DAN SUMBER DATA}

Data yang digunakan pada penelitian ini adalah time series yang merupakan sekumpulan data dari suatu fenomena tertentu yang didapat dalam beberapa interval waktu tertentu periode bulanan yang terdiri dari; (1) data margin pembiayaan perumahan murabahah di Bank Syariah Mandiri Periode April 2005-Oktober 2013 dan Bank BRISyariah periode 2008 - 2013; dan (2) data suku bunga kredit konsumtif pada Bank Swasta Nasional periode April 2005 - Oktober 2013 yang dikeluarkan olah Bank Indonesia.

Dalam pengumpulan data sehubungan masalah yang dibahas dalam penelitian ini dilakukan dengan dua cara sebagai berikut; (1) penelitian kepustakaan (library research), yaitu penelitian guna memperoleh penge-tahuan secara teoritis dengan cara membaca dan mencatat dari berbagai sumber literatur, text book, artikel-artikel, buku-buku ilmiah yang berhubungan dengan masalah yang akan diteliti; dan (2) penelitian lapangan (field research), yaitu penelitian secara langsung ke sumber data untuk mendapatkan data sekitar masalah yang akan diteliti, dengan menggunakan data primer berupa angsuran pem-biayaan perumahan di bank Syariah Mandiri dan bank BRISyariah periode April 2005-Oktober 2013.

\section{VARIABEL - VARIABEL PENELITIAN}

\section{Nilai Rumah Berdasarkan Pembiayaan Murabahah}

Pembiayaan perumahan dengan akad murabahah di Bank Syariah merupakan salah satu pembiayaan yang berbasis Natural Certainty Contract (NCC) yakni akad bisnis yang memberikan kepastian pembayaran baik dari segi jumlah dan waktu (timing).

Margin keuntungan + Harga Beli $=$ Nilai Rumah

\section{Nilai Rumah Berdasarkan Kredit Konvensional \\ Pembiayaan perumahahan pada bank} konvensional menggunakan bunga mengam-bang (floating rate) sebagai dasar acuan besarnya nilai angsuran dengan pola efektif. Perhitungan bunga pembiayaan perumahan dengan bunga effective floating adalah porsi bunga dihitung berdasarkan pokok hutang tersisa.

\section{Nilai Rumah Atas Dasar Harga Pasar}

Pendekatan perbandingan harga jual (sales comparison approach), atau metode perbandingan data pasar yaitu pendekatan dengan mempertimbangkan penjualan dari rumah sejenis atau pengganti data pasar yang terkait, yang nantinya menghasilkan estimasi nilai melalui proses membandingkan objek penilaian dengan transaksi rumah yang sebanding. (Modul Penilaian Pendekatan Data Pasar, 2008).

Harga Jual Rumah Pembanding + Penyesuaian = Indikasi Nilai Rumah 


\section{TEKNIK ANALISA DATA}

Sebelum dilakukan analisis data dilakukan perhitungan nilai Capital gain/loss dari pembiayaan perumahan yang dihitung dengan menggunakan rumus capital gain aktiva tunggal sebagai berikut:

$$
\mathrm{Cg} / \mathrm{l}=\underline{\mathrm{Np}-\mathrm{Hb}} \times 100 \%
$$

$\mathrm{Hb}$

dimana:

$\mathrm{Cg} / \mathrm{l}=$ Persentase capital gain (loss) pembiayaan perumahan selama periode pembiayaan

$\mathrm{Np}=$ Nilai Pasar rumah setelah jatuh tempo pembiayaan

$\mathrm{Hb}=$ Harga Beli

Pengujian terhadap data dan analisa dalam penelitian ini adalah dengan melakukan pengujian hipotesis menggunakan statistik analitik, yaitu dengan menggunakan uji-t (t-test). Uji-t yang digunakan dalam penelitian ini ialah uji t paired sample test). Di mana jumlah sampel $<30$ data dan dengan tingkat kepercayaan 95\%.

\section{HASIL PEMBAHASAN}

\section{NILAI JUAL RUMAH DALAM PEMBIAYAAN}

PERUMAHAN MURABAHAH DAN KREDIT PERUMAHAN KONVENSIONAL

Sebelum menentukan harga jual akad murabahah pada pembiayaan pemilikan rumah, bank syariah menentukan besaran margin dalam bentuk persentase rate tertentu. Rate ini adalah nilai relatif imbal hasil tahunan yang diharapkan oleh bank syariah dari setiap pembiayaan yang tersalurkan dengan besaran yang sudah pasti dan tetap hingga berakhirnya masa pembiayaan. Dengan demikian, total marjin akan ditentukan oleh besarnya plafond dan margin yang dikenakan secara annuitas. Selain itu, total margin juga akan ditentukan oleh jangka waktu pembiayaan yang diberikan kepada nasabah. Semakin panjang jangka waktu pembiayaan, maka dengan plafond dan pricing yang sama total margin akan semakin besar (Karim, 2010).

Dalam kredit perumahan konvensional, suku bunga menjadi dasar untuk menetapkan besaran angsuran pada kredit bank konvensional. Karena suku bunga selalu berfluktuasi tergantung pada kondisi dalam dunia keuangan, maka suku bunga yang dikenakan kepada nasabah juga berfluktuasi. Ini akan masuk akal jika nasabah harus membayar angsuran mereka dalam jumlah yang berbeda untuk setiap bulan tergantung pada suku bunga pada bulan saat pembayaran dilakukan. Sehingga, besarnya keuntungan yang akan diperoleh oleh bank konvensioanl sangat dipengaruhi oleh besarnya fluktuasi bunga bank yang berlaku untuk setiap bulannya. Hal ini disebabkan karena kredit pemilikan rumah konvensional menggunakan bunga floating sebagai dasar penentuan besaran margin keuntungan kredit.

Pada pembiayaan perumahan dengan akad murabahah, bank tidak dapat mengubah angsuran pembiayaan nasabah hingga berakhirnya masa pembiayaan. Ini sebagai akibat harga jual yang telah disepakati di awal pembiayaan. Dengan demikian, pada akad murabahah bank syariah menghadapi risiko income gap yang lebih besar, yaitu pada saat biaya dana meningkat sementara margin akad murabahah yang berjalan tidak dapat diubah.

Ilustrasi komparasi angsuran dalam pembiayaan perumahan menggunakan akad murabahah dan kredit konvensional dapat dilihat pada Gambar 3. Lokasi obyek murabahah tidak ikut mempengaruhi seberapa besar margin yang dibebankan kepada nasabah. Tetapi, besaran margin ini bisa dinegosiasikan antara nasabah dengan bank pada saat awal akad pembiayaan akan dilakukan.

\section{PEMBIAYAAN PERUMAHAN MURABAHAH DI BANK SYARIAH MANDIRI (BSM)}

Komparasi nilai rumah berdasarkan akad murabahah dan kredit konvensional disebab-kan oleh perbedaan penentuan pola margin keuntungan. Berdasarkan Sampel penelitian di atas, 


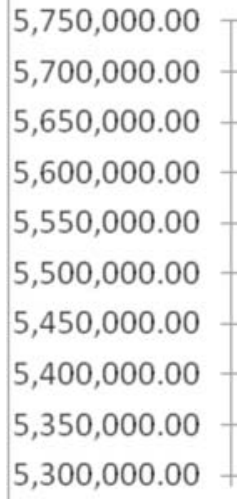

1223445677899101112131415161718192021222324252627282930313233343536

GAMBAR 4. KOMPARASI ANGSURAN PEMBIAYAAN PERUMAHAN DALAM AKAD MURABAHAH DAN KONVENSIONAL Sumber: Bank Syariah Mandiri dan Bank BRISyariah

TABEL 2. SPESIFIKASI SAMPEL NASABAH PEMBIAYAAN PERUMAHAN MRABAHAH

\begin{tabular}{|c|c|c|c|c|}
\hline Sampel & Plafond & Jangka Waktu & Margin Murabahah & Lokasi Obyek Murabahah \\
\hline 1. & \multicolumn{4}{|c|}{ Bank Syariah Mandiri (BSM) } \\
\hline Sampel 1 BSM & $160,000,000$ & 60 bulan & $15.66 \%$ & $\begin{array}{l}\text { Bumi Pelita Kencana B2/9 Kel. Pondok Cabe Udik Kec. } \\
\text { Pamulang, Tangerang Selatan }\end{array}$ \\
\hline Sampel 2 BSM & $375,000,000$ & 60 bulan & $15.66 \%$ & $\begin{array}{l}\text { Kalibata Indah Jl Kesemek S-7 RT.012 RW.006 Kel. } \\
\text { Rawajati Kec. Pancoran, JAKSEL. }\end{array}$ \\
\hline Sampel 3 BSM & $349,000,000$ & 60 bulan & $15.25 \%$ & $\begin{array}{l}\text { Perum Ciputat Baru JL Parkit N0 } 1 \text { RT } 07 \text { RW } 05 \text { Kel Sawah } \\
\text { Lama Kec Ciputat, Kab. Tangerang }\end{array}$ \\
\hline Sampel 4 BSM & $157,000,000$ & 96 bulan & $21.00 \%$ & $\begin{array}{l}\text { Villa Bogor Indah Blok B1 - } 12 \text { A kel. Bogor Kec. Sareal, } \\
\text { Jabar }\end{array}$ \\
\hline 2. & \multicolumn{4}{|l|}{ Bank BRISyariah (BRIS) } \\
\hline Sampel 1 BRIS & $239,000,000$ & 60 bulan & $14.50 \%$ & $\begin{array}{l}\text { Perum Puri Permata Blok E No } 4 \text { Jl. Prof Hamka (Gaga } \\
\text { Caplin) Larangan Selatan Ciledug }\end{array}$ \\
\hline Sampel 2 BRIS & $98,000,000$ & 60 bulan & $15.50 \%$ & $\begin{array}{l}\text { Perum Puri Permata Blok G No } 9 \text { Jl. Prof Hamka (Gaga } \\
\text { Caplin) Larangan Selatan Ciledug }\end{array}$ \\
\hline Sampel 3 BRIS & $100,000,000$ & 60 bulan & $16.50 \%$ & $\begin{array}{l}\text { Waskito Residence Jl. Musholla (Tahap 2) Jatiwaringin } \\
\text { antilop Kav } 22 \text { Kel Jatikramat Kec Pondok Gede Bekasi }\end{array}$ \\
\hline
\end{tabular}

TABEL 3. KOMPARASI NILAI RUMAH MRABAHAHDAN KONVENSIONAL (NASABAH BANK SYARIAH MANDIRI)

\begin{tabular}{clllll}
\hline Sampel & $\begin{array}{l}\text { Harga Beli (Uang Muka } \\
+ \text { Plafond) }\end{array}$ & Margin Murabahah & Bunga Konvensional & $\begin{array}{l}\text { Nilai Rumah Berdasarkan } \\
\text { Pembiayaan Murabahah }\end{array}$ & $\begin{array}{l}\text { Nilai Rumah Berdasarkan } \\
\text { Kredit Konvensional }\end{array}$ \\
\hline & $a$ & $b$ & $c$ & $(a+b)$ & $(b+c)$ \\
\hline Sampel 1 BSM & $200,000,000$ & $71,722,629$ & $69,006,210$ & $271,722,629$ & $269,006,210$ \\
Sampel 2 BSM & $536,250,000$ & $168,099,913$ & $161,542,529$ & $704,349,913$ & $697,792,529$ \\
Sampel 3 BSM & $500,000,000$ & $163,005,821$ & $150,211,992$ & $663,005,821$ & $650,211,992$ \\
Sampel 4 BSM & $195,250,000$ & $136,225,760$ & $119,811,451$ & $331,475,760$ & $315,061,451$ \\
\hline
\end{tabular}


TABEL 4. KOMPARASI NILAI RUMAH MRABAHAHDAN KONVENSIONAL (NASABAH BANK BRISYARIAH)

\begin{tabular}{llllll}
\hline Sampel & $\begin{array}{l}\text { Harga Beli (Uang Muka } \\
\text { + Plafond) }\end{array}$ & Margin Murabahah & Bunga Konvensional & $\begin{array}{l}\text { Nilai Rumah Berdasarkan } \\
\text { Pembiayaan Murabahah }\end{array}$ & $\begin{array}{l}\text { Nilai Rumah Berdasarkan } \\
\text { Kredit Konvensional }\end{array}$ \\
\hline A & B & $c$ & $(a+b)$ & $(b+c)$ \\
\hline Sampel 1 BRIS & $300,000,000$ & $98,395,551$ & $103,221,644$ & $398,395,551$ & $403,221,644$ \\
Sampel 2 BRIS & $173,000,000$ & $43,432,764$ & $42,162,761$ & $216,432,764$ & $215,162,761$ \\
Sampel 3 BRIS & $196,220,000$ & $47,507,127$ & $43,079,715$ & $243,727,127$ & $239,299,715$ \\
\hline
\end{tabular}

TABEL 5. BIAYA PEMBANGUNAN RUMAH TINGGAL DI JAKARTA

\begin{tabular}{cll}
\hline No & Kategori Rumah & Harga Per m2 \\
\hline 1. & Rumah Standar 1 Lantai & Rp. 2,000,000,- s.d Rp. 2,500,000,- \\
2. & Rumah Standar 2 Lantai & Rp. 2,500,000,- s.d Rp. 2,800,000,- \\
3. & Rumah Menengah 2 lantai & Rp. 2,800,000,- s.d Rp. 3,000,000,- \\
4. & Rumah Mewah 2 lantai & Rp. 3,000,000,- s.d Rp. 3,500,000,- \\
5. & Rumah Lux 2 lantai & Rp. 3,800,000,- s.d Rp. 4,000,000,- \\
\hline
\end{tabular}

nilai rumah berdasarkan akad murabahah sedikit lebih tinggi jika dibandingkan dengan pembiayaan berdasarkan akad konvensional yakni rata-rata sekitar $0.9 \%$ - 5\%, tergantung pada tenor (jangka waktu) pembiayaan. Selisih nilai rumah pada pembiayaan perumahan murabahah dan konvensioanal dengan tenor 5 tahun adalah $0.9 \%$ $1,9 \%$, dan untuk tenor 8 tahun adalah sebesar $5 \%$.

Hasil penelitian ini menunjukkan bahwa penentuan besaran margin antara pembiayaan dengan akad murabahah dan kredit konvensional tidak berbeda jauh. Dan makin mempertegas penelitian yang sudah dilakukan Chong dan Liu, (2009) bahwa pricing pembiayaan murabahah masih menggunakan suku bunga sebagai benchmark pembiayaan perumahan di bank syariah.

\section{Pembiayaan Perumahan Murabahah di Bank Brisyariah (BRIS)}

Berdasarkan Sampel penelitian di Bank BRISyariah, selisih nilai rumah berdasarkan akad murabahah dibandingkan dengan pembiayaan berdasarkan kredit konvensional yakni sekitar 0.6\% - 1.8\% atau antara Rp. 1.270.000 - Rp. 4.826.093,. Jangka waktu pembiayaan adalah selama 5 tahun dengan plafon pembiayaan yang berbeda-beda.

Bank BRISyariah memberlakukan tingkat margin yang berbeda-beda untuk tiap nasabah. Seperti pembiayaan perumahan pada Sampel 1 dengan lokasi obyek murabahah di Perum Puri Permata Blok E Larangan Selatan Ciledug dengan plafon pembiayaan bank sebesar Rp. 239.000.000,dengan margin $14.50 \%$ p.a diperoleh nilai rumah berdasarkan pembiayaan dengan akad murabahah sebesar Rp. 398.395.550,70,- dan jika dihitung dengan menggunakan suku bunga kredit konsumtif menurut bank swasta nasional maka diperoleh nilai rumah sebesar Rp. 403.221.643,93,- Pembiayaan perumahan dengan menggunakan suku bunga kredit konsumtif menurut bank swasta nasional lebih mahal Rp 4.826.093,23,- atau selisih sebesar $1.2 \%$ jika dibandingkan dengan nilai jual rumah dengan akad murabahah. 


\section{Nilai Rumah Setelah Jatuh Tempo Pembiayaan Berdasarkan Nilai Pasar}

Tahapan yang harus dilakukan adalah dengan menentukan nilai pasar tanah dengan menganggap tanah tempat rumah ini berdiri sebagai tanah kosong kemudian membandingkan harga tanah masing-masing data pembanding. Sedangkan untuk menghitung nilai bangunan, perlu dilakukan perhitungan perkiraan jumlah uang yang dikeluarkan untuk membangun atau mengganti properti baru yang meliputi biaya atau harga bahan, upah buruh, biaya tenaga ahli dan semua yang berkaitan seperti biaya angkutan, biaya pemasangan, atas setiap $\mathrm{m} 2$ dari luas bangunan.

Nilai bangunan yang sudah diketahui, perlu dilakukan perhitungan nilai penyusutannya. Perhitungan penyusutan atas sebuah rumah sangat ditentukan oleh berapa lama umur ekonomis/ umur manfaat dari properti tersebut. Umur ekonomis obyek penelitian ini yang berupa rumah tinggal tipe menengah (standar) yakni 30 tahun dan tipe menengah mewah adalah 40 tahun (MAPPI, 2014).

Berdasarkan hasil retaksasi yang telah dilakukan terhadap obyek murabahah setelah pembiayaan jatuh tempo diketahui bahwa nilai pasar Sampel 1 yang terletak di Bumi Pelita Kencana, Pondok Cabe Kecamatan Pamulang Tangerang Selatan adalah Rp. 277,370,000 atau lebih tinggi nilainya Rp. 5,647,370 jika dibandingkan dengan nilai rumah berdasarkan pembiayaan murabahah dan lebih tinggi sebesar Rp. 8,363,790 jika dibandingkan dengan nilai rumah berdasarkan kredit konvensional.

Nilai taksasi rumah yang menjadi agunan sampel 2 adalah Rp 536,250,000,-. Setelah lima tahun pembiayaan berjalan (pembiayaan jatuh tempo), nilai retaksasi obyek murabahah tersebut diketahui nilai pasarnya sudah meningkat lebih dari tiga kali lipatnya atau menjadi Rp. 1,765,110,000,-. Dibandingkan dengan nilai rumah berdasarkan pembiayaan perumahan murabahah yang sebesar Rp. 704,349,913.19,- maka terdapat selisih nilai sebesar Rp. 1,060,760,086.81,- terhadap nilai pasar . Dan jika dibandingkan dengan nilai rumah berdasarkan kredit konvensional maka terdapat selisih nilai sebesar Rp. 1,067,317,470.87,-. Kondisi ini menunjukkan bahwa kenaikan nilai properti (rumah) di Kalibata sangat signifikan.

Nilai taksasi rumah yang menjadi agunan sampel 3 adalah Rp 500,000,000,-. Setelah lima tahun pembiayaan berjalan (pembiayaan jatuh tempo), retaksasi dilakukan terhadap obyek murabahah tersebut dan diketahui bahwa nilai pasarnya sudah meningkat lebih dari empat kali lipatnya atau menjadi Rp. 2,111,270,000,-. Dibandingkan dengan nilai rumah berdasarkan pembiayaan perumahan murabahah yang sebesar Rp. 663,005,820.69,- maka terdapat selisih nilai sebesar Rp. 1,448,264,179,-. Dan jika dibandingkan dengan nilai rumah berdasarkan kredit konvensional maka terdapat selisih nilai sebesar Rp. 1,461,058,008,-. Kondisi ini menunjukkan bahwa kenaikan nilai properti (rumah) di Ciputat sangat signifikan.

Nilai taksasi rumah berdasarkan nilai pasar rumah untuk Sampel 4 setelah pembiayaan jatuh tempo adalah $\mathrm{Rp} 331,475,760$,- atau lebih tinggi nilainya Rp. 11,991,239,-jika dibandingkan dengan nilai rumah berdasarkan pembiayaan murabahah dan lebih tinggi nilainya sebesar Rp. 28,405,549,jika dibandingkan dengan nilai rumah berdasarkan kredit konvensional.

Berdasarkan hasil retaksasi yang penulis lakukan terhadap obyek murabahah setelah pembiayaan jatuh tempo diketahui bahwa nilai pasar Sampel 1 Bank BRI Syariah adalah Rp. 436,822,500 atau lebih tinggi nilainya Rp. 38,426,949,-. jika dibandingkan dengan nilai rumah berdasarkan pembiayaan murabahah dan jika dibandingkan dengan nilai rumah berdasarkan kredit konvensional maka nilai pasar rumah setelah jatuh 
tempo pembiayaan akan lebih tinggi sebesar Rp. 33,600,856,-. Hasil retaksasi nilai pasar Sampel 2 Bank BRISyariah adalah Rp. 242,711,250 atau lebih tinggi nilainya Rp. 26,278,486 jika dibandingkan dengan nilai rumah berdasarkan pembiayaan murabahah dan lebih tinggi nilainya sebesar Rp. 27,548,489 jika dibandingkan dengan nilai rumah berdasarkan kredit konvensional.

Nilai taksasi rumah yang menjadi agunan pada Sampel 3 Bank BRISyariah adalah Rp 196,220,000,-. Setelah lima tahun pembiayaan berjalan (pembiayaan jatuh tempo), retaksasi dilakukan terhadap obyek murabahah tersebut dan diketahui bahwa nilai pasarnya sudah meningkat menjadi Rp. 426,594,000,-. Dibandingkan dengan nilai rumah berdasarkan pembiayaan perumahan murabahah yang sebesar Rp. 243,727,126.58,- maka terdapat selisih nilai sebesar Rp. 182,866,873. Dan jika dibandingkan dengan nilai rumah berdasarkan kredit konvensional Rp. 239,299,715.48,- maka terdapat selisih nilai sebesar Rp. 187,294,285,--

Kenaikan nilai rumah yang sangat signifikan setelah pembiayaan jatuh tempo disebabkan oleh banyak faktor yang mempengaruhi. Sebagaimana temuan pene-litian Fahirah et al. (2010) bahwa faktor-faktor yang mempengaruhi nilai tanah dan bangunan pada perumahan adalah:

\section{Faktor Lokasi dan Aksesibilitas}

Faktor lokasi dan aksesibilitas rumah akan menentukan nilai ekonomi rumah tersebut. Kenaikan nilai properti (rumah) pada SampelSampel penelitian dipengaruhi oleh lokasi yang cukup strategis dari masing-masing Sampel dan didukung oleh aksebilitas yang baik, serta rencana pembangunan fasilitas infrastruktur dimasa mendatang akan sangat mendukung aksebilitas menuju obyek penelitian. Seperti akses jalan Tol JORR (Jakarta Outer Ring Road) yang mendukung akses menuju Pondok Cabe, Ciputat, Kalibata,
Jatiwaringin, Ciledug dan jalan Tol BORR (Bogor Outer Ring Road/Sentul Selatan) yang memudahkan akses ke Bogor serta rel kereta dan feeder APTB (Angkutan perbatasan terintegrasi busway) menjadikan lokasi obyek penelitian yang terletak Ciputat dan pondok Cabe cukup mudah dicapai. Kondisi ini menjadikan harga rumah naik dengan cepat dan cukup signifikan melebihi nilai rumah berdasarkan pembiayaan murabahah maupun konvensional. Rencana pembangunan ruas tol Depok-Antasari dan Cinere-Bogor-Jagorawi juga ikut mendongkrak nilai rumah yang berada di kawasan Ciledug, Pondok Cabe, serta Ciputat.

\section{Faktor Ketersediaan Fasilitas.}

Fasilitas yang dimaksudkan adalah fasilitas pendidikan tinggi, jaringan air bersih, jaringan listrik, jaringan telepon, sarana pendidikan, tempat ibadah, pelayanan kese-hatan, pusat perbelanjaan, sarana kebersihan dan persampahan. Keberadaan fasilitas pendidikan tinggi, keberadaan beberapa fasilitas perbelanjaan modern ikut mendorong meningkatnya kebutuhan akan tempat tinggal di Ciputat, Pondok Cabe, Ciledug, Kalibata, Jatiwaringin.

\section{Faktor Ekonomi}

Keterbatasan lahan dan mahalnya tempat tinggal di Jakarta, membuat masyarakat perkotaan menyasar pinggiran kota seperti Depok, Bogor, Tangerang, Bumi Serpong Damai, Bekasi, untuk mencari tempat tinggal. Kondisi ini mendorong munculnya embrio-embrio real estate, dengan model cluster-cluster perumahan kecil yang kurang dari 2 hektar. Tingginya permintaan lahan perumahan di pinggiran kota Jakarta mendorong harga rumah naik cukup tinggi.

\section{Faktor sosial}

Ditunjukkan dengan karakteristik pendu-duk 
TABEL 6. CAPTALGAN LOSSPEMBIAYAAN PERUMAHAN MURABAHAH

\begin{tabular}{|c|c|c|c|c|}
\hline No & $\begin{array}{l}\text { Nilai Rumah Berdasarkan } \\
\text { Pembiayaan Murabahah }\end{array}$ & $\begin{array}{l}\text { Nilai Rumah Berdasarkan Harga } \\
\text { Pasar }\end{array}$ & $\begin{array}{l}\text { Selisish Harga Pasar VS } \\
\text { Murabahah }\end{array}$ & Capital Loss \\
\hline & a & $b$ & $c ;(b-a)$ & $(c: a)$ \\
\hline \multicolumn{5}{|c|}{ Bank Syariah Mandiri (BSM) } \\
\hline 1 & $271,722,629$ & $277,370,000$ & $5,647,370$ & $2.1 \%$ \\
\hline 2 & $704,349,913$ & $1,765,110,000$ & $1,060,760,087$ & $151.6 \%$ \\
\hline 3 & $663,005,821$ & $2,111,270,000$ & $1,448,264,179$ & $218.4 \%$ \\
\hline 4 & $331,475,760$ & 343.467 .000 & $11,991,239$ & $3.6 \%$ \\
\hline \multicolumn{5}{|c|}{ Bank BRISyariah } \\
\hline 1 & $398,395,551$ & $436,822,500$ & $38,426,949$ & $9.6 \%$ \\
\hline 2 & $216,432,764$ & $242,171,250$ & $26,278,486$ & $12.1 \%$ \\
\hline 3 & $243,727,127$ & $426,594,000$ & $182,866,873$ & $75.0 \%$ \\
\hline
\end{tabular}

seperti jumlah penduduk dan kepadatan penduduk pada Sampel-Sampel penelitian. Sebagai contoh kepadatan penduduk kecamatan Pamulang yang mencapai 10.674 orang/Km2 dan kepadatan penduduk kecamatan Ciputat yang mencapai $10.457 \mathrm{orang} / \mathrm{Km}^{2}$. Interaksi faktor-faktor tersebut di atas menciptakan nilai yang tercermin dalam prinsip ekonomi permintaan dan penawaran. Permintaan juga dipengaruhi oleh keinginan untuk memuaskan kebutuhan tetapi dibatasi oleh kemampuan daya beli. Seperti pada permintaan, penawaran suatu komoditas dipengaruhi juga oleh kegunaan dan keterbatasan di pasar. Sebagaimana yang dikemukakan Wolcott (1987) bahwa konsep nilai suatu properti (rumah) ditimbulkan karena adanya faktor-faktor ekonomi berupa kegunaan (utility), kelangkaan (scarcity), keinginan (desire/ demand), serta daya beli efektif (effective purchasing power).

Nilai rumah dari sampel-sampel penelitian berdasarkan nilai pasar rumah setelah jatuh tempo pembiayaan lebih tinggi nilainya jika dibandingkan dengan nilai rumah berdasarkan pembiayaan perumahan murabahah dan kredit perumahan konven-sional. Pembiayaan murabahah mengandung risiko spesifik yang berbeda baik dengan skema pembiayaan syariah lainnya maupun kredit konvensional berbasis bunga yakni risiko terkait harga jual (Rahmawaty, 2007).

Perbandingan nilai rumah setelah jatuh tempo pembiayaan dengan nilai rumah berdasarkan pembiayaan murabahah maupun konvensional menjadi tolak ukur untung tidaknya perbankan dalam melakukan bisnis pembiayaan perumahan. Kondisi ini berbeda dengan akad lain, seperti akad bagi hasil (mudharabah dan musyarakah) dan akad sewa (ijarah), dimana bank syariah memiliki kesempatan untuk membuat klausul perubahan (review) pricing pembiayaan selama masa berjalannya pembiayaan.

\section{EVALUASI POLA PEMBIAYAAN YANG LEBIH MENGUNTUNGKAN DAN COCOK UNTUK MENGATASI VOLATILITAS HARGA RUMAH.}

\section{Capital Gain/Loss Pembiayaan Perumahan}

Murabahah dan Kredit Konvensional

Dari Tabel 7 diketahui nilai capital loss tertinggi pembiayaan perumahan Bank Mandiri Syariah terdapat pada Sampel 3 sedangkan nilai capital loss pembiayaan perumahan BRISyariah tertinggi terdapat pada Sampel 3 yaitu 75\%. Berdasarkan Tabel 8 diketahui capital loss tertinggi terdapat pada 
TABEL 7. CAPTALGAN LOSSKREDIT PERUMAHAN KONVENSIONAL

\begin{tabular}{lllll}
\hline No & $\begin{array}{l}\text { Nilai Rumah } \\
\text { Berdasarkan Kredit } \\
\text { Konvensional }\end{array}$ & $\begin{array}{l}\text { Nilai Rumah } \\
\text { Berdasarkan Harga } \\
\text { Pasar }\end{array}$ & $\begin{array}{l}\text { Selisish Harga Pasar } \\
\text { VS Konvensional }\end{array}$ & Capital Loss \\
\hline \multicolumn{1}{l}{ a } & b & $c ;(b-a)$ & (c:a) \\
\hline 1 & $269,006,209$ & $277,370,000$ & $8,363,790$ & $3.1 \%$ \\
2 & $697,792,529$ & $1,765,110,000$ & $1,067,317,471$ & $152.9 \%$ \\
3 & $650,211,992$ & $2,111,270,000$ & $1,461,058,008$ & $224.7 \%$ \\
4 & $315,061,451$ & 343.467 .000 & $28,405,549$ & $9.0 \%$ \\
Bank BRISyariah & & & \\
1 & $403,221,644$ & $436,822,500$ & $33,600,856$ & $8.3 \%$ \\
2 & $215,162,761$ & $242,711,250$ & $27,548,489$ & $12.8 \%$ \\
3 & $239,299,715$ & $426,594,000$ & $187,294,285$ & $78.3 \%$ \\
\hline
\end{tabular}

TABEL 8. HASIL UJI BEDA FIESTPEMBIAYAAN MURABAHAH DAN KREDIT KONVENSIOANAL ATAS NASABAH BANK SYARIAH MANDIRI

\begin{tabular}{lll}
\hline & Nilai Rumah Murabahah VS & $\begin{array}{l}\text { Nilai Rumah Konvensional } \\
\text { VS Nilai Pasar }\end{array}$ \\
\hline Hipotesis $0\left(\mathrm{H}_{0}\right)$ & Tidak Labir & Tidak Lebih Menguntungkan \\
Hipotesis $1\left(\mathrm{H}_{1}\right)$ & Lebih Menguntungkang & Lebih Menguntungkan \\
Sig $(2$ tailed $)$ & 0,191 & 0,191 \\
Keputusan & Terima $\mathrm{H}_{0}$ & Terima $\mathrm{H}_{0}$ \\
\hline
\end{tabular}

TABEL 9. HASIL UJI BEDA FIESTPEMBIAYAAN MURABAHAH NASABAH BANK BRISYARIAH

\begin{tabular}{|c|c|c|}
\hline & $\begin{array}{l}\text { Nilai Rumah Murabahah VS } \\
\text { Nilai Pasar }\end{array}$ & $\begin{array}{l}\text { Nilai Rumah Konvensional VS } \\
\text { Nilai Pasar }\end{array}$ \\
\hline Hipotesis $\mathrm{O}\left(\mathrm{H}_{0}\right)$ & Tidak Lebih Menguntungkan & Tidak Lebih Menguntungkan \\
\hline Hipotesis $1\left(H_{1}\right)$ & Lebih Menguntungkan & Lebih Menguntungkan \\
\hline Sig (2 tailed) & 0,243 & 0,243 \\
\hline Keputusan & Terima $\mathrm{H}_{0}$ & Terima $\mathrm{H}_{0}$ \\
\hline
\end{tabular}

Sampel 3 yaitu 224.7\% sedangkan terendah terdapat pada Sampel 1 yaitu $3.1 \%$.

Sedangkan nilai capital loss pembiayaan perumahan Bank BRISyariah jika dihitung berdasarkan suku bunga kredit konsumtif menurut bank swasta nasional adalah $8.3 \%-78.3 \%$, dimana nilai capital loss tertinggi terdapat pada Sampel 3 yaitu $78.3 \%$ sedangkan nilai capital loss terendah $8.3 \%$.

\section{UJ BEDA DUA RATA-RATA (T-TEST PAIRED}

Sampel Test) Pembiayaan Murabahah dan Kredit

\section{Konvensional.}

Uji beda menggunakan T-test Paired Sampel Test dengan level of signifikan 95\%. Nilai thitung yang dihasilkan adalah sebesar -1.945 pada derajat bebas 2 dengan sig 0.191. Karena sig (2-tailed) > 0.05, maka keputusan pengujian ialah menerima hipotesis nol $\left(\mathrm{H}_{0}\right)$. Dengan demikian, dapat dikatakan bahwa pembiayaan perumahan murabahah di bank Syariah Mandiri tidak lebih menguntungkan daripada perhitungan berdasarkan nilai pasar rumah setelah jatuh tempo pembiayaan. Sedangkan hasil pengujian nilai rumah 
berdasarkan kredit perumahan konvensional dengan nilai pasar rumah setelah jatuh tempo pembiayaan diketahui nilai t-hitung yang dihasilkan adalah sebesar -1.949 pada derajat bebas 2 dengan sig 0.191. Karena sig (2-tailed) > 0.05, maka keputusan pengujian ialah menerima hipotesis nol $\left(\mathrm{H}_{0}\right)$.

Berdasarkan hasil pengujian nilai rumah berdasarkan pembiayaan murabahah dengan nilai pasar rumah setelah jatuh tempo pembiayaan, maka diketahui nilai t-hitung Dengan demikian, dapat dikatakan bahwa pembiayaan perumahan atas nasabah bank Syariah Mandiri jika dihitung menggunakan suku bunga kredit konsumtif bank swasta nasional juga tidak lebih menguntungkan daripada perhitungan berdasarkan nilai pasar rumah setelah jatuh tempo pembiayaan, yang mananilai hitung yang dihasilkan adalah sebesar 1.634 pada derajat bebas 2 dengan sig 0.243. Karena sig (2-tailed) > 0.05, maka keputusan pengujian ialah menerima hipotesis nol $\left(\mathrm{H}_{0}\right)$.

Dari hasil analisis statistik tersebut dapat dikatakan bahwa pembiayaan perumahan murabahah di bank BRISyariah tidak lebih menguntungkan daripada perhitungan berdasarkan nilai pasar rumah setelah jatuh tempo pembiayaan.

Hasil pengujian nilai rumah berdasarkan kredit perumahan konvensional dengan nilai pasar rumah setelah jatuh tempo pembiayaan diketahui nilai thitung yang dihasilkan adalah sebesar -1.578 pada derajat bebas 2 dengan sig 0.254. Karena sig (2tailed) $>0.05$, maka keputusan pengujian ialah menerima hipotesis nol $\left(\mathrm{H}_{0}\right)$. Dengan demikian, dapat dikatakan bahwa pembiayaan perumahan atas nasabah bank BRISyariah jika dihitung menggunakan suku bunga kredit konsumtif bank swasta nasional juga tidak lebih menguntungkan daripada perhitungan berdasarkan nilai pasar rumah setelah jatuh tempo pembiayaan.

Sebagaimana yang tertulis pada hasil uji beda dua rata-rata ( $t$ - test paired Sampelt test), pada kondisi ini menunjukkan bahwa pricing pembiayaan murabahah maupun pricing pembiayaan konvensional masih belum bisa mengakomomodir perubahan harga rumah yang naik secara simultan dan signifikan walaupun pembiayaan perumahan dengan menggunakan akad murabahah lebih menguntungkan jika dibandingkan dengan menggunakan akad konvensional. Sehingga perlu diberlakukan model akad-akad lainnya yang sesuai ketentuan syariah yang bisa diterapkan sebagai pengganti ataupun sub-stitusi akad murabahah. Seperti penerapan akad ijarah yang selama ini sudah berjalan, dengan produk Ijarah mumtahiya bit tamlik ataupun akad Musyarakah Mutanaqishah.

\section{SIMPULAN}

Beberapa kesimpulan yang dapat diambil dari hasil penelitian ini antara lain adalah bahwa nilai rumah berdasarkan pembiayaan murabahah pada Bank Syariah Mandiri jika dibandingkan dengan kredit perumahan konvensional dengan tenor pembiayaan 5 tahun lebih tinggi 0.9\% - 1.9\%. Dan untuk tenor pembiayaan 8 tahun, nilai rumah berdasarkan pembiayaan murabahah lebih tinggi 5\% dibandingkan nilai rumah berdasarkan kredit konvensional. Sedangkan selisih nilai rumah berdasarkan pembiayaan murabahah di Bank BRISyariah jika dibandingkan dengan kredit perumahan berdasarkan suku bunga konvensional dengan tenor pembiayaan 5 tahun yakni sekitar $0.6 \%-1.8 \%$.

Selanjutnya, nilai rumah berdasarkan pembiayaan perumahan di bank Syariah Mandiri dan Bank BRISyariah dengan akad murabahah maupun berdasarkan kredit perumahan konvensional memiliki selisih nilai yang cukup signifikan jika dibandingkan dengan nilai pasar rumah setelah jatuh tempo pembiayaan. Selain itu, pembiayaan perumahan murabahah lebih 
menguntungkan jika dibandingkan dengan kredit perumahan konvensional. Akan tetapi pembiayaan perumahan dengan akad murabahah maupun degan kredit konvensional, kedua pola pembiayaan tersebut tidak cocok diaplikasikan jika dimaksudkan untuk mengatasi volatilitas harga rumah.

Dari hasil penelitian ini, implikasi penting yang dapat dijadikan masukan dalam praktik perbankan syariah terkait isu manajemen risiko di pembiayaan kepemilikan rumah dengan knsep murabahah, yaitu perlu diimplementa-sikan model-model alternatif akad di dalam pembiayaan kepemilikan perumahan untuk mengatasi volatilitas harga rumah.

Penelitian ini memiliki keterbatasan yakni hanya menguji pada kasus di tempat tertentu dan pembiayaan murabahah pada dua bank syariah. Selain itu, tahun yang dibandingkan tidak sama karena keterbatasan akses pemerolehan data oleh peneliti. Berdasarkan keterbatasan tersebut maka sangat dianjurkan untuk berhati-hati dalam hal penyimpulan secara umum atas kasus serupa yang terjadi di tempat berbeda. Selain itu, oleh sebab penelitian ini masih merupakan penelitian awal dan dalam pandangan penulis masih merupakan inisiatif penelitian yang perlu dikembangkan lebih lanjut serta disempurna-kan, maka sangat disarankan untuk para akdemisi, peneliti dan praktisi untuk mengem-bangkan penelitian ini guna memberikan sumbangsih bagi perkembangan ilmu ekonomi syariah baik secara teoritis maupus praktis.

\section{DAFTAR PUSTAKA}

\section{Al-Qur'an al-Karim}

Al-Mutairi, Humoud. A Comparison Betwen Islamic and Conventional Home Financing in Kuwait: Client Perceptions of The Facilites Offered by The National Bank of Kuwait and Kuwait Finance House. Durham Theses. Durham University. 2010.

Al-Marghinani, 1957, "Al-Hidaya", translated into English by Charles Hamilton. Premier Book House, Lahore.

Anton, A. (2006). ANALISIS MODEL VOLATILITAS RETURN SAHAM
(Studi Kasus pada Saham LQ 45 di Bursa Efek Jakarta) (Doctoral dissertation, program Pascasarjana Universitas Diponegoro).

Antonio, Muhammad Syafii. Bank Syariah Dari Teori Ke Praktik. Jakarta Gema Insani Press, 2009.

Chong, B.S. \& Liu, M.H. (2009). Islamic banking: interest free or interest-based? Pacific Basin Finance Journal, 17, 125-144.

Eckert, J.K. Property Appraisal and Assessment Administration, IAAO Chicago Illinois. 1990

Fahirah, F. 2012. Identifikasi Faktor yang Mempengaruhi Nilai Jual Lahan dan Bangunan Pada Perumahan Tipe Sederhana, Jurnal SMARTek, Vol. 8 No. 4, 2010.

Hamid, Ayesha, dan Omar Masood. Selection Criteria for Islamic Home Financing: A Case Study of Pakistan. Journal of Qualitative Research in Financial Markets. Volume 3. Issue 2. P. 117-130. Emerald Group Publishing. 2011.

Hanif, Muhammad dan Syed Tahir Hijazi. Islamic House Financing: A Critical Analysis and Comparison With Conventional Morgage. Middle Eastern Finance and Economics. Issue 6. 2010

Hanley, N., \& Spash, C. L. (1993). Cost-benefit analysis and the environment (Vol. 499). Cheltenham: Edward Elgar.

Hardjono. Mudah Memiliki Rumah Lewat KPR. Jakarta: PT. Pustaka Grahatama, 2008.

Ismal, Rifki. Assessing Moral Hazard Problem in Murabahah Financing. Journal of Islamic Economics, Banking and Finance. Volume-5 Number-2. P.102-112. 2009.

Karim, Adiwarman Azwar. Bank Islam: Analisis Fiqih dan Keuangan. Jakarta: Rajawali Pers, 2010.

Maali, B., Casson, P., \& Napier, C. (2006). Social reporting by Islamic banks. Abacus, 42(2), 266-289.

Nugroho, R., 2006. Analisis faktor-faktor yang Mempengaruhi kinerja karyawan (Studi Empiris pada PT. Bank Tabungan Negara (Persero), Cabang Bandung). Tesis. Program Studi Magister Manajemen Program Pasca Sarjana Universitas Dipenogoro.

Rama, Ali, Wisnu Wardhana, Farid Kurnia Rahman, Ilham Reza Ferdian. Islamic Benchmarking an Alternative to Interest (Evidence from Home Financing in Malaysia). Islamic Economics and Finance Pedia. International Islamic University Malaysia. 2011.

Rahmawaty, A. (2007). Ekonomi Syari'ah: Tinjauan Kritis Produk Murabahah dalam Perbankan Syari'ah di Indonesia. Jurnal Ekonomi Islam: La Riba, 1(2), 189-203.

Rivai, V., 2005. Performance Appraisal. Jakarta: Raja Grafindo Persada Sutawijaya, A. 2004. Analisis- Faktor-faktor Yang Mempengaruhi Nilai Jual TanahSebagai Dasar Penilaian Nilai Jual Objek Pajak (NJOP) PBB di Kota Semarang. Jurnal Ekonomi Pembangunan, 9 (1), 6578

Walcott, Richard C. The Appraisal of Real Estate American Institute of Real Estate Appraiser. North Michigan. Chicago Illonois. 1987. Wiryono, Sudarso Kaderi, Barli Suryanta, dan Oktofa Yudha Sudrajad. Analysis on The Dynamics of Yield Curve of Murabaha in Indonesian Sharia Morgage Financing: The Case of Indonesian Sharia Banks. Annual International Conference on Micro and Macro Economics. 2011.

Zandi, Gholamreza, Noraini Mohd. Ariffin and Alireza Shahabi. 2012. Some Issues on Murabahah Practices in Iran and Malaysian Islamic Banks. African Journal of Business Management Vol. 6 (24), pp. 7066-7073.

Fatwa dan Peraturan Perundangan: Departemen Keuangan Republik Indonesia. Modul Penilaian Pendekatan Data Pasar. Dikeluarkan 
oleh Pusat Pendidikan dan Pelatihan Keuangan Umum Badan Pendidikan dan Pelatihan Keuangan untuk DTSS Penilaian Properti Dasar. 2008

Fatwa DSN-MUI NO: 04/DSN-MUI/IV/2000 Tentang Murabahah.

Fatwa DSN-MUI NO: 13/DSN-MUI/IX/2000 Tentang Uang Muka Dalam Murabahah.

Fatwa DSN-MUI NO: 16/DSN-MUI/IX/2000 Tentang Diskon Dalam Murabahah.

Fatwa DSN-MUI NO: 17/DSN-MUI/IX/2000 Tentang Sanksi atas Nasabah Mampu yang Menunda-nunda Pembayaran.

Fatwa DSN-MUI NO: 23/DSN-MUI/III/2002 Tentang Potongan Pelunasan Dalam Murabahah.

Fatwa DSN-MUI NO: 84/DSN-MUI/XII/2012 Tentang Metode Pengakuan Keuntungan Al-Tamwil Bi Al-Murabahah (Pembiayaan Murabahah) di Lembaga Keuangan Syariah.

Peraturan Mahkamah Agung Republik Indonesia Nomor 02 Tahun 2008 Tentang Kompilasi Hukum Ekonomi Syariah.

Kamus Besar Bahasa Indonesia.

http://www.mappi.or.id/static-321-umur-ekonomis.htm

http://www.bi.go.id. 